Београд

\title{
СРБИ У ПОМОРИШЈУ: ИЗМЕЪУ СЕЛА И ГРАДА
}

На основу теренских истраживања Срба у Арадској жупанији (2013-2015) у раду се анализирају биографски наративи о одласцима из села и пресељењу у град Арад, као и фрагменти биографских прича забележени у форми дигресија у оквиру конверзацијских наратива на теме традицијске културе. Коришћена је грађа из насеља Моноштор, Мунара, Наћфала, Торња и Фелнак, затим из града Арада, као и сећања жртава комунизма објављених у историографским изворима. Временски период обухваћен у наративима почиње од периода комунизма, преко Револуције 1989. све до савременог света румунске посттранзиције. Наративи су подељени у пет тематских целина који покривају садашње стање у насељу, сећања на фелначки тамбурашки оркестар чији су сви чланови запослени у једној градској фабрици, одласке у Арад из дечије перспективе, фрагменте о свакодневици у Араду и данашњу ситуацију располућености између села и града. Приложени транскрипти су дословни и одражавају различите степене очуваности српског језика (шумадијсковојвођанског дијалекта) и одговарајући утицај румунског језика код сваког појединог саговорника.

Кључне речи: депопулација, радне миграције, Срби у Румунији, усмена историја, биографске приче, Арад.

'Град' у наслову овог прилога припада истраживачком метајезику: Срби у Поморишју би рекли: варош. Та варош за њих је Арад, али је за многе, као и већину Срба у Румунији, град у који се одлази, између осталог и зато да би се школовање наставило на српском језику, па се тамо касније и дефинитивно пресељава, обично - Темишвар. ${ }^{3}$ Овај прилог се пак, бави само градом Арадом у коме је могућност да се користи матерњи језик сведена на породицу, пријатеље и Текелијину цркву. ${ }^{4}$

\footnotetext{
${ }^{1}$ biljana.sikimic@bi.sanu.ac.rs

${ }^{2}$ Рад је настао у оквиру пројекта „Истраживање културе и историје Срба у Румунији” ЦНИКСР.

${ }^{3}$ Само један саговорник из Поморишја истраживачима је говорио о свом некадашњем животу и раду у Букурешту (касније се са породицом вратио у Арад и своје родно село). О Србима у Букурешту в. студије Неделку и Чолевић, 2016, 2017.

${ }^{4}$ Настава српског језика у Поморишју била је једна од тема истраживача Балканолошког
} 
Теренска грађа из данашњег румунског дела Поморишја, на којој се заснива овај прилог, прикупљена је током тимских теренских истраживања Балканолошког института САНУ започетих крајем новембра 2013. године, затим настављених током јуна 2014. и јуна 2015. у оквиру међуакадемијске размене САНУ и Румунске академије наука и пројекта „Срби у Румунији и румунско-југословенске везе у другој половини 20. века” (руководиоци пројекта су били академик Војислав Становчић и др Миодраг Милин). ${ }^{5}$ У прилогу се користи само мали део тада прикупљене теренске документације и то из насеља Наћфала (рум. Satu Mare), Фелнак (рум. Felnac), Моноштор (рум. Mănăştur), Мунара (рум. Munar) и Торња (рум. Turnu). Према попису из 2011. године у Наћфали је живело 115 Срба, у Фелнаку - 162 (у овом селу се налази и једина основна школа на српском језику и Арадској жупанији), у Моноштору - 11, у Мунари - 27, и у Торњи - 35. Данас је тај број вероватно знатно нижи. За град Арад и његово данашње предграђе Арад Гај постоје само збирни демографски подаци - укупно 425 , што износи само $0,3 \%{ }^{6}$ Некадашње сеоско насеље Арад Гај, још у међуратном периоду интегрисано у град Арад, повезано је трамвајском пругом са центром и није узето у обзир у овом прилогу, а историја овог данас приградског насеља исцрпно је осветљена у низу монографија локалног активисте Љубомира Шандића (уп. нпр. Шандић, 2011, 2012). ${ }^{7}$

института САНУ и приликом теренског рада у оквиру пројекта „Истраживање културе и историје Срба у Румунији” Центра за научна истраживања и културу Срба у Румунији при Савезу Срба у Румунији током 2016. године. Том приликом прикупљена документација обједињена је са грађом из претходних истраживања Поморишја у студији Светлане Ћирковић која анализира актуелно стање наставе српског језика у насељима Фелнак, Арад Гај и Велики Семпетер (Ћирковић, 2017).

${ }^{5}$ Теренски рад са Србима у Арадској жупанији у периоду 2013-2015. омогућио је и непосредно организовао господин Драган Воштинар, потпредседник Савеза Срба у Румунији. Од велике помоћи истраживачима на терену била је и антрополог др Елена Родика Колта (Elena Rodica Colta), као и сарадници на пројекту - др Миодраг Милин и др Андреј Милин. Сви снимљени разговори и фотографије архивирани су у Дигиталном архиву Балканолошког института САНУ и доступни су на интерној мрежи САНУ. У прилогу су коришћени транскрипти 11 разговора из Дигиталног архива Балканолошког института САНУ: Felnak 1 BS (2013), Monoštor 1 SĆ (2014), Munara 1 SĆ (2014), Naćfala 1 SĆ (2013), Naćfala 1 BS (2013), Naćfala 3 BS (2013), Tornja 1 BS (2013), Tornja 4 BS (2013), Tornja 5 BS (2013), Tornja 1 SĆ (2013), ME Arad LJĐ (2015). Истраживачи: Биљана Сикимић (БС), Светлана Ћирковић (Ch) и Љубица Ђурић (љЂ). Транскрипција Биљана Сикимић.

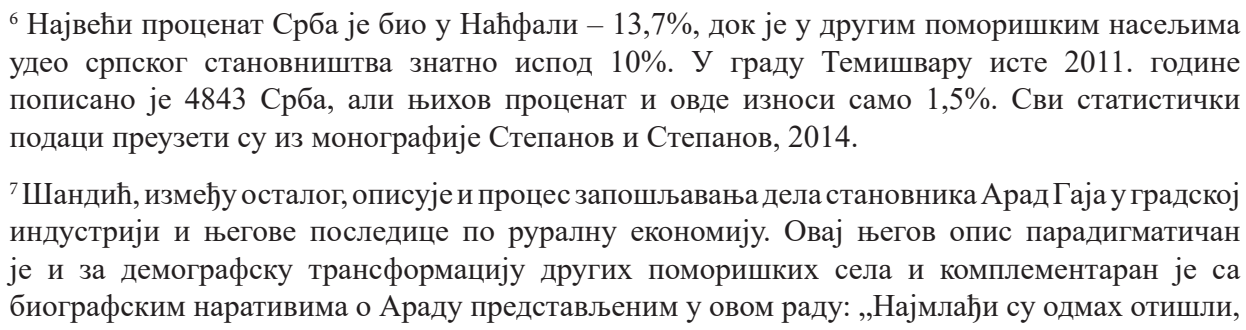


Сва истраживана сеоска насеља у Поморишју су етнички мешовита и у свима су Срби мањина: јавно декларисани позитивни ставови о мултиетничности и интеркултуралности, као и вредностима мултикултурализма важе само за 'старо' стање, не и за новодосељене Румуне који насељавају куће дефинитивно одсељених Немаца, што је тема за посебно истраживање (уп. Colta, 2010).

Присуством Срба у граду Араду у новије време бави се серијска публикација Арад кроз време, у форми зборника научних и публицистичких радова нешто мањег обима и научних амбиција, а као резултат редовних годишњих скупова који се одржавају у овом граду почевши од 1999. године. У питању су доминантно историографски прилози на српском и румунском језику посвећени историји града и животу Срба у њему, затим знаменитим Србима (пореклом из Арада, али и не само Арада), манастиру Бездин и другим српским црквама. Истраживачима је на располагању и монографија историчара Љубивоја Церовића (Церовић, 2007), а Араду у периоду социјализма посвећена је, између осталих, и тротомна монографија на румунском језику (Nițu, 2017).

Прилог се састоји од одломака из транскрипата разговора систематизованих у пет тематских целина: ставови о депопулацији поморишких руралних средина, сећање на чланове тамбурашког оркестра из Наћфале запослене у фабрици у Араду, град Арад из перспективе сеоског детета, индивидуална искуства о пресељењу у град и повратак у родно село и, на крају, данашње стање располућености између живота у граду и родног села. Као наслови одељака издвојени су цитати из одабраних текстова, што је, уосталом, као и сам избор и систематизација - ауторски чин којим се овај прилог делимично удаљава од уобичајене научне методологије. Као документ $^{8}$ у форми полилога, ова збирка различитих сећања може се читати и као засебна целина. Полилог који води десетак саговорника из пет различитих насеља садржи њихове биографске приче и локалне историје испричане

после првих година колективизације (да се разуме 1962-1964) иако су тада резултати били добри, ка индустрији, док су се други професионално оспособили баш у тим арадским фабрикама, зато што је месечна плата била привлачна а исто су им се, мало касније, нудили и станови, а све је то било лепше од рада у пољу и башти. У колективу су остали старији, који више нису имали ни вољу а ни моћи за рад у индустрији... Остали су код куће. Свака кућа имала је башту, а та је била и извор прихода, зато што су ови људи радили, а не ленчарили. Они су производили не само за њих, него и за њихову децу и унуке који живе у арадским солитерима. Треба подвући да је део варошана долазио у помоћ својим родитељима. Арадске пијаце биле су пуне производа из гајчанских башти.” (Шандић, 2012: 181, у питању је дослован, нелекторисан цитат; наиме, језик Љубомира Шандића, близак локалном говору Поморишја, заслужује посебну лингвистичку анализу).

${ }^{8}$ Екстракција 'документарних' елемента из интегралних транскрипата разговора представља сложени задатак (јер је, у крајњој консеквенци, цео снимљени разговор - документ). 'Документарност' као истраживачки циљ је имплицитна приликом институционалних интервјуа, посебно када је саговорник унапред упознат са планираним темама. 
'делимичном' странцу - истраживачу са којим се дели исти језик и који долази из матичне државе, али који, због различитог историјског искуства, не може да буде упућен у све околности живота у периоду комунизма и транзиције у Румунији. ${ }^{9}$

За разумевање стварности свакодневице Срба у Поморишју у периоду комунизма одличан извор представља монографија Стевана Бугарског и Љубомира Степанова („Кад Мориш потече кроз перо”). Монографија је била објављена 1991. године, али је грађа за кратке слике о сваком од насеља прикупљена током лета 1989, дакле, непосредно пре Револуције. Написана у духу социјалистичког реализма, ова монографија с поносом помиње централне репере арадског социјалистичког урбанитета: све фабрике, међу којима посебно текстилну фабрику, нову робну кућу „Зиридаву”, новоизграђене станове, фудбалски клуб УТА, а посебну пажњу поклања врло развијеном културном животу града (Бугарски и Степанов, 1991: 36, 36, 39-42, 92-94). Монографија зрачи атмосфером одушевљења успесима социјалистичке производње у граду и ентузијазмом који људи на селу имају за рад у пољопривредним 'колективима'. ${ }^{10}$ На делу је глорификација колективног рада и такмичарског радног духа, иначе, у директној супротности са исказима саговорника који следе у овом прилогу а усмерени су искључиво на приватну својину и индивидуална радна и животна постигнућа $[8,9,10,14] .{ }^{11}$

Осим прикупљања језичке документације, временски ограничени на само четири до пет радних дана, истраживачи Балканолошког института на терену Поморишја углавном су се оријентисали на теме из традицијске кул-

\footnotetext{
${ }^{9}$ Дијалектолог Гордана Драгин (Драгин, 2020: 187) описује свој неспоразум на терену око употребе термина информатор. Наиме, саговорници још увек памте негативно значење овог термина из времена репресије и доминантне улоге Секуритате (у румунској теренској лингвистици и антропологији данас је у употреби термин: interlocutor, еквивалент српском: саговорник).

${ }^{10}$ Утисци из једнодневне посете селу Наћфали обављене лета 1989. године пренети су у форми репортаже: „Председника Пољопривредне производне кооперативе Владу Воштинара чекали смо дуго. Стигао је, најзад, на бициклу, прашњав али оран: био је да процени јечам и чини му се биће добра жетва. На председничко место изабран је од скоро. (...) Сада кооператива располаже са 1573 хектара обрадиве земље и 204 хектара пашњака и сенокоса. (...) Истини за вољу, није ни земља као на другим странама, као у Печки и Винги, па да се Наћфала хвата у коштац са њима. Нека их, нека обарају рекорде у производњи житарица, а овде се спрема изненађење: држаће се житарица - пшеница, јечам, кукуруз, не може село без тога, али ће полако прелазити на поврће, најпре и највише на купус. Са улице Милорад Петков дозива председника: треба да пођу на договор у Предузеће за механизацију. Стасити, црномањасти Влада Воштинар устаје, облачи блузу. Супруга га опомиње да није ручао (схватамо то као прекор нама што смо га задржали). Он сталожено полази: ништа за то, није му први пут; нека она послужи нас, а он ће боље вечерати...” (Бугарски и Степанов, 1991: 78-79).

${ }^{11}$ Ставови о раду Срба из насеља Банатске Црне Горе као и њихов однос према запослењу у граду (Темишвару), на основу етнолингвистичке теренске грађе анализирани су у прилогу: Сикимић, 2019.
} 
туре које се могу повезати са заштитом нематеријалне културне баштине и чине део колективног памћења. У питању су календарски обичаји, пре свега, Божић ${ }^{12}$ и литије поводом других празника, ${ }^{13}$ затим обичаји животног циклуса - свадба (али се она истраживачима често прича из личне перспективе саговорника као једног од учесника), обичаји везани за годишње клање свиња, ${ }^{14}$ историју локалних црквених хорова. Сећања везана за теме из области усмене историје - обавезан рад у 'колективу' и принудно пресељавање у Бараган - углавном су персонализована и у форми су биографских или породичних прича (за разлику од усмене историје о досељавању и за живот и опстанак заједнице пресудних збивања у некадашњој Војној граници током 18. века, која и данас чини централни идентитетски наратив Срба у Поморишју, уп. Сикимић, 2015). ${ }^{15}$ Све остале теме зависиле су од расположења и иницијативе саговорника. Биографске приче нису током овог истраживања посебно и систематски елицитиране, ова се тема отварала само ако би саговорник преузео иницијативу током разговора и желео да говори о себи и својој породици (што се током антрополошко лингвистичког теренског истраживања са отвореним упитником повремено дешава, обично на крају разговора или ако саговорнику није довољно објашњен циљ интервјуа). Питања о животу у граду, која би евентуално поставио истраживач, пре су била куртоазне природе у циљу јачања поверења у истраживача.

Тако су на маргинама интервјуа саговорници из Поморишја причали историју своје заједнице и историју своје породице, јасно маркирајући свој етнички, верски и језички идентитет (у неким случајевима порекло и статус истраживача који долази из Југославије често је довољан мотив да се говори о себи), узгредно коментарисале политичке околности (мада таква питања истраживачи нису постављали). Као допуну 'прећутане', политичке историје у овај прилог укључен је и један разговор [9] чије су основне теме политичка репресија и траума, преузет из већ објављених извора. Осим овог, сви други саговорници у прилогу су анонимни. Женски 'гласови' нису по-

12 Традиционална израда чеснице за Божић као још увек живо наслеђе Срба у Поморишју било је предмет истраживања Светлане Ћирковић (Ћирковић, 2015 - где је истовремено детаљно описана и теренска методологија примењивана приликом овог истраживања; Ćirković, 2015, 2016).

13 Истраживачи Етнографског института САНУ, у оквиру поменутог пројекта Центра за научна истраживања културе Срба у Румунији, у Фелнаку су током 2018. године истраживали славске обичаје, уп. Трубарац Матић, 2019. Етнолог Андреј Милин у својим истраживањима промена у традиционалној српској породици у Румунији обухватио је и простор Поморишја (Milin, 2003)

${ }^{14}$ УП. студије Sikimić, 2015 и Сикимић, 2015, 2016.

${ }^{15} \mathrm{O}$ депопулацији као последици расељавања Поморишја после развојачења Војне границе и сеобе Срба у Русију у 18. веку в., између осталог, Степанов и Бугарски, 2004. Сећање на успостављање државне границе Румуније и Мађарске, којим је од румунског Поморишја одвојено насеље Батања, требало би да буде тема посебног рада. 
себно издвојени: теренско искуство је показало да су за теме везане за традицијску културу (данас углавном за њену реконструкцију) жене погоднији саговорници, а у пракси се разговори са мушкарцима често своде на усмену и породичну историју, у случају Поморишја и на црквени живот.

Одабрани наративи осветљавају локални систем вредности на фону релације село - град, а депопулација се као црвена нит провлачи кроз све разговоре. Ипак, издвојени су само ставови о депопулацији као последици емиграција из села у градове, али не и други важни разлози депопулације, као што је то негативан природни прираштај - који су саговорници такође повремено помињали (У пошли у варош, отишли, нису се вратили више [1], они стари људи млоги су отишли у варош [2]). Друге чворишне теме до којих је спонтано долазило јесу старост сеоског становништва (они други који су остали све остариду, остариду, остариду [2]), затварање школа на српском језику и смањивање броја активних верника у цркви (ти млади не дођеду тако у иркву [2]). Говорило се и о самачкима домаћинствима као последици депопулације и високе просечне старости становништва (Већином шта умиреду су стари и сами (..) и то жене, све су старе, све су прико осамдесет и пет, осамдес шест, саме, немаду никог. [3] $)^{16}$

Без обзира на то што је аутор прилога као заједничку нит извукао 'град', фокус наратива је увек на самом саговорнику, омогућен спонтаним одмицањем од почетно инициране теме традицијске културе (о феномену дигресија у теренском интервјуу в. Ћирковић, 2004). Саговорници говоре оно што лично знају, што су лично доживели и видели. Дакле, није у питању препричано, већ непосредно знање, непосредно искуство (на језичком нивоу изражено галголима сетити се, знати), а које указује на то да је процес сећања, присећања у току:

Онда, шта се ја сећам, смо имали тамбураше [4]

Оних старих ја се не сећам, али ови нови се сећам [4]

То су били у оркестру који се ја сећам [4]

чекајте да се сетим, Миле, Миле Никић [4]

ја се сетим јел ја сам вуко млека у Арад [7]

Данас знам да покажем кут'е ди сам вуко [7]

Позивање на себе, као сведока и актера, битно је за фолклористичко одређивање одабраних наратива као жанра биографске приче. ${ }^{17}$ Ипак, посматрано и даље из фоклористичког угла, неопходни елемент 'поновљивости' практично је немогуће установити на терену, односно, веома је тешко знати да ли је у питању прича о себи коју саговорник и иначе повремено

${ }^{16}$ Књижевница Јаворка Марков Јоргован у својим радовима често проблематизује тему старења и депопулације насеља српског становништва Поморишја, уп., на пример, Марков Јоргован, 2001.

${ }^{17}$ Савремена фолклористика у новије време знатну пажњу поклања свакодневном животу у граду у оквиру рада на усменој историји, уп. Петровић, 2015, 2018. 
прича свима који желе да га слушају или је у питању ad hoc прича поверена само истраживачу. Провера припадности фолклорном жанру могућа је само ако на њено понављање укаже неко из саговорникове близине, што је обично ситуација која се на терену намерно избегава. Друга врста понављања неке биографске приче током самог разговара среће се приликом интервјуисања старих људи, али су на терену такве ситуације прилично ретке. У таквом случају, приликом дефинисања жанра фолклориста се мора позабавити и психологијом.

баш ја сам био једне зиме за једног Светог Саву [7]

кад сам ја био дете [2]

Ја кажем за мене, ја већ нећу бити жив [3]

на пример, код мене кад сам крстио, имам два сина [4]

Па пре, кад сам био дете, кад сам ја дошо у Арад [6]

Саговорник некада говори у име своје породице (што се изражава употребом инклузивног мu), а што постаје јасно тек из ширег контекста:

ми кад смо стигли кући ми смо радили, ми смо оно време мећали (=саговорник и његова супруга) [8]

то кад је било лето ми смо узели кончед, као да радимо то [8]

Ми смо морали д идемо кући, смо имали радње, да радимо [8] (=можда се односи на све раднике из Наћфале који су били у сличном статусу радникапољопривредника)

тамо смо направили стан, то није државни, то смо ми, ми правили [11]

син ми инџилир, и ми правимо пројекте за куће [17]

Ми смо отшли тамо, сам имо стан [14]

шта да радимо. Ми смо задовољни [16]

Ситуација у којој саговорник говори у име своје локалне заједнице (овде - Срба у Поморишју) јавља се само у једном одабраном примеру. То не значи да оваквих ситуација у транскриптима нема много више, на пример када се говори о историји црквених хорова, али је употреба иклузивног ми тада лингвистички маркер за други жанр - пре свега за усмену историју:

ми смо, ми смо овде на крају српства, на граници српства у Румунији, од нас онамо нема више Срба [14]

Осим истраживачевих директних питања наведених у заградама и означеним курзивом, присуство истраживача је видљиво на разним другим нивоима. Некада је у питању директна провера правилно забележеног, јер истраживач, осим што снима диктафоном, истовремено нешто бележи у свеску (Милан Митров, сте га написали? БС: Јесам.) У неколико случајева $[3,10]$ запажа се упорно саговорниково реферисање на истраживача и провера његовог разумевања што је свакако индивидуална одлика самог саговорника, ипак, у транскрипту нема евентуалних истраживачевих потврдних одговора али је разумевање саопштеног вероватно било сигнализира- 
но неким гестом. Језички коментари дати су у напоменама, а односе се на етимологију одређене лексеме, њен ареал употребе поређењем са лексиком потврђеном у Речнику српских говора Војводине, семантичке калкове према румунском изворнику, преводе са румунског и слично. ${ }^{18}$ За лингвистичку анализу говора у насељима јужно од Мориша релевантан је дијалектолошки опис говора Наћфале, Драгане Радовановић (2019), а језичке одлике говора Торње, северно од Мориша, чине се ближим говору Батање у Мађарској.

\section{Млоги су отишли у варош}

Осим у Арад, људи из Поморишја одлазе и у Темишвар. ${ }^{19}$ Последице по српску заједницу која је остала у селу су непоправљиве и у том погледу нико од саговорника није био оптимиста:

[1] Овде Срба има око двадесет, двадесет и три лица. (СЋ: Само толико?) Само толико. Једно дванајс куће. (Сћ: Јел некада било више?) Некада било о-о, око три стотине, четир стотине људи. (СЋ: И где су сада они?) Умрели сви. И пошли у варош, отишли, нису се вратили више. Продали куће и. (Ch: А где су обично одлазили, у Арад или у Темишвар?) У Темишвар. И у Арад, а у Араду мало њи, у Араду нема толико Срба, мало има. Ал су отишли у Темишвар. (CЋ: А кад су почели да одлазе у Темишвар?) Педесете, педесет и треће, четврте, до шездесете. (Ch: A што баш тад?) Тако је дошло колектив ${ }^{20}$ и се мењао влада, се мењао, не. И су отишли. [Моноштор, 2014]

[2] И тако је било до хиљаду девет стотине, онда се направила ова црква, се служило само српски овде, а, и кад сам ја био дете, око педесет и треће, четврте године, црква је била пуна, а сад они стари људи млоги су отишли у варош, они други који су остали све остариду, остариду, остариду, и ти млади не дођеду тако у цркву. Све држиду они српске обичаје, а почне глобализација. [Фелнак, 2013]

[3] (CЋ: Мислим, ипак ће бити Срба у Наћфали.) Да, па нећеду пропасти још, кад још осамедест, каже, три, четир, значи да још има. А докле ће трајати, то могу да Вам кажем. Већином шта умиреду су стари и сами. ${ }^{21}$ Па, како да вам

18 У прилогу се не реферише на постојећу лингвистичку литературу о румунским позајмљеницама и калковима која је у новије време већ исцрпно описала већину ових феномена, уп. Бошњаковић и Радан 2010.

${ }^{19}$ О Србима у Темишвару постоји неколико квалитетних монографских студија (нпр. Бугарски и Степанов, 2008, 2011; Павловић, 2012) као и бројни специјализовани мањи прилози (нпр. Бугарски, 2004, Касаш, 2020 и серија радова етнолога Мирјане Павловић).

${ }^{20}$ Сви саговорници доследно користе термин колектив, за разлику од вероватно службеног назива ове институције код Срба у Румунији - пољопривредна производна кооператива, уп. Бугарски и Степанов, 1991: 71.

${ }^{21}$ О синтакси релативизатора шта у банатским говорима в. Бошњаковић, Урошевић, 2013. 
избројим тако, само ту на Велики сокак треба да имамо, један, два, три, четир, пет, шест, седам, осам. Осам и то жене, све су старе, све су прико осамдесет и пет, осамдес шест, саме, немаду никог. Знате колико још може да живи? Коју годину оде и те. После њи ћеду остарити ови други још. И тако да пада здраво. Ће пасти, Наћфала ће пасти село. За двадсет година не знам колко Србина ће бити оде у Наћфалу, не знам. Ја кажем за мене, ја већ нећу бити жив. Ни не мислим кад сад имам седамдес четри, још двадсет година деведес четри. Јa ћу живити до деведес четри године? Не би верово. [Наћфала, 2013]

\section{Сви су били запослени у Араду}

Прича о фелначком тамбурашком оркестру чији су сви чланови били запослени у Араду испричана је из два угла. Скоро у сваком српском поморишком насељу током двадесетог века постојао је тамбурашки оркестар, а у којој мери је његова активност била значајна за локалне заједнице може се сагледати из чињенице да се и данас памте имена његових чланова: године 1989. Стеван Бугарски и Љубомир Степанов, у то време новинари из Темишвара, успели су да попишу имена чланова тамбурашких оркестара из међуратног периода у Арад Гају, ${ }^{22}$ Фенлаку, ${ }^{23}$ Моноштору, Торњи, Наћфали (Бугарски и Степанов, 1991: 160-162). ${ }^{24}$

Саговорник из Фелнака са којим је разговор вођен 2013. године сећа се свих, или скоро свих чланова тамбурашког оркестра, његовог, вероватно, последњег састава, а за неке од тамбураша даје и одређене биографске податке [4]. За овај прилог од велике је важности чињеница да су сви чланови овог оркестра већ били запослени и арадским фабрикама $[4,5]$.

[4] Онда, шта се ја сећам, смо имали тамбураше, тамбурашки оркестар, који је имао, сад ја не знам то, значи, који се састојо од, све оне инструменте које имао осим виолине. Од примице, брач, па и тако даље оно све што се садржи један оркестар. Значи, како да кажем, на сваки инструмент, на сваки инстру-

${ }^{22}$ Састав тамбурашког оркестра из Арад Гаја који узгред помиње саговорник из Торње [5], поименично је пописан у монографији о Поморишју Бугарског и Степанова (1991: 161) и монографији Арад Гаја Љубомира Шандића (2011: 35-36).

23 „Према казивању Фенлачана, њихов тамбурашки збор био би најстарији у Поморишју: основан је још 1904. године. Неко време наступали су заједно са хором, учествујући на свечаностима приређеним приликом државних празника, на омладинским забавама и на свадбама, у месту, али и у Араду, Арад-Гају, Иратошу, Торњи, Печки, Кетфељу итд. По традицији нису имали уз себе посебне певаче, него су певали сви групно, остављајући и по томе јединствени утисак у широј околини. Оркестар се одржао до наших дана. Његов последњи састав изгледао је овако: Сава Митров, прима; Милутин (Гута) Сележановић, терцприма; Драгомир Филиповић, терц-прима; Пера Нецин, терц-прима; Милан Митров, брач; Трајан Никић, бегеш; уз њих је свирао Миливој Никић, на хармоници.” (подаци су вероватно добијени од једног од чланова оркестра, Пере Нецина, уп. Бугарски и Степанов, 1991: 161).

${ }^{24}$ О тамбурашким оркестрима у Темишвару в. рад етномузиколога Марије Думнић (2017). 
мент је био тамбураш. Било седам, осам, не знам колко. Ту смо имали старе тамбураше, па после ове нове. Оних старих ја се не сећам, али ови нови се сећам. Да кажем који су били. Био је Филиповић Драгомир, мислим да се звао Филиповић Драгомир, у загради - Цоју су му казали, Цоју, не знам зашто. Цоју ${ }^{25}$ то је иначе једна тако мала, мало стаколце из које се пије ракија, а он је воло по мало то. Био је и солиста, одличан солиста и примаш. Па онда су били Пера Нецин, сад ја не знам те инструменте, госпођо, да Вам кажем, брач или тако нешто, Пера Нецин. Па чика Милан Митров, па неки Трајан Никић, он је био бегешар, Трајан Никић. Арманику је свиро Никић, Никић, чекајте да се сетим, Миле, Миле Никић. Касније је посто свештеник, али сирома кроз годину дана се упокојио, је имао оно у крв, рак у крви. [...] Значи, смо имали тамбурашки оркестар, само да нисам казо све, значи Филиповић Драгомир, сам га казо, звани Цоју, Пера Нецин, чика Милан Митров, Милан Митров, сте га написали? (БС: Јесам.) Да. И Трајан Никић. Е, био је и Јефта, Јефта Митров, ту има више инструмената, не знам ни ја баш све. И Јефта Митров. То су били у оркестру који се ја сећам. Е овај оркестар из Фелнака, ми смо, ми смо овде на крају српства, на граници српства у Румунији, од нас онамо нема више Срба, ${ }^{26}$ само у Араду. Су свирали недељом игранке, сва српска кола, па и оно модерно у оно време валцер и шта ти ја знам, танго. [...]. Значи, су свирали свадбе, разне прославе, српске мислим, на рођендане. Ето, на пример, код мене кад сам крстио, имам два сина, у Темишвару су обадва, на крштење ми свирали они, значи ко их је звао. А свирали су они већина, значи сви, не већина, сви су били запослени у Араду, у фабрику вагона. Се звала UVA, по румунском Uzina de vagoane Arad, UVA, Фабрика вагона у Араду. Е, ту су долазили у посетама Деж, па после Чаушеску. Е толико су били препознати да директор фабрике их је звао на банкету на крају, се завршило банкетом кад су ови завршили посету, Чаушеску поготово, и се завршило банкетом, они су били звати да свирају, да се веселу тамо. А су знали и румунске, не само српске, и румунске, и сви ови које сам казо, сви су били и певачи добри, сви су били добри певачи. [Фелнак, 2013]

[5] (БС: Ко је знао да свира овде у Торњи?) Били су Цигани који су свирали лепо у та времена и добро. И после за ове српске су се донели тамбураши јел из Гаја, били су из Гаја тамбураши, Гаји су имали лепе и добре тамбураше. И после су се и на Светог Саву, смо и донели из Фелнака. Сад не знам да кажем тачно које године, баш ја сам био једне зиме за једног Светог Саву са соницама. За шес сати зајутра сам стиго у Арад, они ондак су изашли из фабрике. Било је зима једно, ја знам, минус десет, петнес, сам имо шубе, бунде, како ви кажете то? (БС: Бунда.) И куване ракије и вина и су се пењали у сонице су се, су се увели, су и спавали, а кад су стигли на крај села су извадили тамбуре, су скочили како су свирали. (БС: Ови из Фелнака?) Да. [Торња, 2013]

\footnotetext{
${ }^{25}$ Рум. țoi, 'чокањче, фићок'.

${ }^{26}$ Сличног је мишљења књижевница Јаворка Марков Јоргован, у свом раду о српској културној баштини она бележи да су поморишка села „српска мртва стража” (рум. fruntarii moarte ale sârbilor), Marcov Iorgovan 2018: 116.
} 


\section{Пре, кад сам био дете}

Одломци који следе рефлектују перспективу једног детета са села (из Наћфале) које ретко одлази у град и другог детета (из Торње) које је приморано да свакодневно иде у град и разноси млеко купцима по кућама. ${ }^{27}$ У првом примеру [6] сећање се односи на послератни период када је одлазак у град детету са села био доживљај који се памти и који је причињавао радост. Други пример [7] се вероватно временски смешта у нешто ранији период, у време Другог светског рата или непосредно после рата када је у Торњи цветала индивидуална пољопривредна производња (узгред се у наративу помиње цена уља јер је овом фрагменту претходила прича о доброј заради од продаје уља од бундеве - олаја).

[6] Па пре, кад сам био дете, кад сам ја дошо у Арад, у две године једаред да ми купи мама аљине, знате како се радујем, па кад се попнем у ајзибан ${ }^{28}$ сам био радостан, дођем, се возам, дете са села. Ја кад сам дошо у професионалну у школу, ја још нисам видио телевизор. У оно време је имао покојни прота наш у Наћфали и још један човек. Нисам ја отшо код проте да видим као дете телевизор јел то, јер ја нисам видо један меч, дивизија ${ }^{29} \mathrm{~A}$, као УТА ${ }^{30}$ је била онак и то, кад сам отишо први пут као прост, били су петнес хиљада стадиони, као дете, дете са села. Знате како је то било, да. [Арад, 2015]

[7] Четир леја је била литра, ја се сетим јел ја сам вуко млека ${ }^{31}$ у Арад сваког петка. Данас знам да покажем кут'е ди сам вуко, је био метут лонац и под лонца новце. И колко новце је било метуто, толике литре млека сам. Тамо сам водио једно две године, у тај сокак, са млеком. Ја нисам позно газде коме сам носио млека и знам да четри леја је било олај ${ }^{32}$, а ниси га мого продати увек, па силно олаја је било. Силно. [Торња, 2013]

\section{После смо се приместили у Арад}

Одломак који следи [8] вођен је као неформални разговор, није имао институционални оквир и одвијао се спонтано у близини Текелијине цркве

\footnotetext{
${ }^{27}$ Причања о детињству новија су истраживачка тема у савременој фолкористици, уп. Marković, 2012.

${ }^{28}$ Ајзибан, ајзлибан, 'воз'. РСГВ потврђује ову лексему у многим насељима у Војводини и код Срба у Мађарској.

${ }^{29}$ Рум. divizie, 'лига'.

${ }^{30}$ УТА, фудбалски клуб из Арада.

${ }^{31}$ Калк према румунском a căra lapte, 'возити/вући/носити млеко'.

${ }^{32}$ Олај, 'уље, зејтин'. РСГВ потврђује ову лексему у многим насељима у Војводини, као и код Срба у Мађарској и Румунији.
} 
у Араду. Истраживач (БС) покушава да разјасни правни статус становника града који је у периоду комунизма у Румунији обезбеђивала одговарајућа лична карта (булетин). Саговорник је био запослен у фабрици и поседовао арадска лична документа, али му она нису дозвољавала да се свакодневно враћа у родну Наћфалу и тамо бави пољопривредом, нити је имао право на месечну карту за превоз возом до свог села, чини се да ова рестриктивна правила истраживачу остају нејасна до краја разговора (Док нисте имали тај булетин за град путовали сте у село, сваког дана сте ишли из Наћфале? (..) Али макар тај воз је ишао редовно?).

[8] Ја већ сам имо, ја и Милан смо имали гарсоњеру, смо добили од фабрике, на ту базу ${ }^{33}$ сам мого да правим булетин ${ }^{34}$ за град. Ниси мого друкчије и на ту базу после кад сам се оженио сам мого да правим блок, ${ }^{35}$ ако ниси имо булетин за варош, за град ниси мого да. [...] (БС: Док нисте имали тај булетин за град путовали сте у село, сваког дана сте иили из Наћфале?) Ниси мого. Да, да. Госпоја, у четир сата смо морали да устанемо зајтре, ја и моја супруга. У полак пет смо се кренули од куће и си имо до станице петнес минута. И ту на, око пет без нешто ${ }^{36}$ дошо ајзибан, ми тако смо спавали у ајзибан, до Арада сат времена. Кад смо ишли кући, у четир сата се крено, у три сата изиђеш, они су, није било леба на селу, си требо да тражиш да купиш леба, тако нас је држо Чаушеску, на, да те бог склони. И онак, од четир до пет и нешто спавамо. У ајзибан, спаваш. А не, сви спавамо тако, заш ми кад смо стигли кући ми смо радили, ми смо оно време мећали по три, четри хиљаде струка пардајса, пасте, не на пијацу, него ишо експорт га узимо, и долазили из Западне Немачке су га носили, цело село је мећало тај, тај пардајс. Е кад је дошла револуција, готово, више не треба никоме, не знам шта је, све је, све је то. Пази, у оно време да правиш по тридесет хиљада леја, поред салара, ${ }^{37}$ добро то, да није била мати не би, али мати така вредна била, и за Делију се бринила и за Бранку, и скувана вечера и обран три хиљаде струка пардајса и онак се метули у шопру ${ }^{38}$ и бирај га, заш ниси мого гата ${ }^{39}$, га изручим, не, не, то је требало све убрисан, метут по. Било три, три, како се каже, три дименсиуне, ${ }^{40}$ како се каже, већи, средњи и мањи, знате. И то си требо да га мериш, шес кила да има тачно. Сандук је имо кило и нешто и после кад си га придо, ти га прегледо, си требо да га улепиш с неком артијом и. Тако је било. Али смо легли увече, смо

\footnotetext{
${ }^{33}$ Калк према румунском: pe bază astă, 'на основу тога'.

${ }^{34}$ Рум. buletin, 'лична карта'.

${ }^{35}$ Рум. bloc, 'стан у згради'.

${ }^{36}$ Калк према румунском: cinci fără ceva, 'нешто пре пет'.

${ }^{37}$ Рум. salar, 'плата'.

${ }^{38}$ Шопра, 'шупа, помоћна зграда'. РСГВ потврђује ову лексему код Срба у Румунији и у источном Банату.

${ }^{39}$ Рум. gata, 'готово'.

${ }^{40}$ Рум. dimensiune, 'величина'.
} 
легли око два сата, у четир смо морали д устанемо. Онак, мож да мисте какви смо били ми уморни. Зато ја нисам знао море, то кад је било лето ми смо узели кончед ${ }^{41}$, као да радимо то, да, тако је било. И на ту базу смо купили блок. Што сам ја имо булетин за град друкчије, а после револуције си мого да купи ко. А онак тако је држо Чаушеску да ако немаш булетин за варош не можеш да купиш блок. (БС: Иако радите, иако имате посо у варошу?) Не, не, не. (БС: Значи посо у варошу Вам није гарантовао да станујете?) Није ништа, ништа, ништа, не. (БС: Али макар тај воз је ишао редовно?) Ишо редовно, а шта, вите, после није, није било слободно, кад имаш булетин за варош да имаш абонамент. ${ }^{42}$ И ја и Милан, овај, црквењак, тај. Онак смо средили у предузеће нам је давала она да мож да га. Ал је казала: „Пазите, дође контрола.” Да не [?]. Иште булетин, и булетин види да имаш за варош. И онак шта смо радили, смо сишли у какво село и, доле и, прошо ајзибан смо узели други, ил смо изашли на неку оказију ${ }^{43}$, ил смо узели машину ${ }^{44}$ да не туримо ове који су нам дали, знате то да. Ми смо морали д идемо кући, смо имали радње, да радимо. [Арад, 2015]

Следећи одломак [9] представља изузетак у овом низу транскрипата теренских разговора јер је преузет из збирке разговора које су током 2010. године водили (и објавили у посебној монографији) румунски историчар Миодраг Милин и сарадници са жртвама политичких процеса у Румунији у периоду комунизма (Милин, Милин и Михајлов 2011). Већина ових интервјуа објављена је новинарски приређеној форми, али су уз монографију приложени оригинални снимци разговора омогућили израду потпуног транскрипта. Саговорник историчара Миодрага Милина је био Живко Илин, рођен у Наћфали, а ухапшен 1961. као средњошколац у Печки из политичких разлога. У одломку [9] Илин сведочи о проблемима са којима се суочио у Араду по повратку са робије где је иначе изучио столарски занат. ${ }^{45}$ Нема велике разлике у примењеној методологији вођења теренског разговора у односу на методологију коју су примењивали сарадници Балканолошког института, разлика је само у личности истраживача: наиме, историчар Миодраг Милин (ММ) долази са Института за банатске студије у Темишвару, одлично је упознат са целокупним историјским и политичким контекстом, осим тога саговорник нема потребе да му преводи цитате разговора вођене на румунском језику на које реферише у својој биографској причи. Истраживачеви коментари и умешно постављена питања, са своје стране,

\footnotetext{
${ }^{41}$ Рум. concediu, 'годишњи одмор'.

${ }^{42}$ Рум. abonament, 'претплатна карта'.

${ }^{43}$ Рум. ocazie, 'прилика'.

${ }^{44}$ Рум. mașină, 'аутомобил'.

45 Делови интервјуа са Живком Илином објављени су у: Милин, Милин и Михајлов, 2011: 196-201, али су сви оригинални румунски цитати преведени на српски језик, будући да је монографија намењена српским читаоцима.
} 
сведоче о његовој упућености у специфичне и трагичне околности из савремене румунске историје (оном систему требали су такви људи. ММ: Је био по мери сваког система, да, да. (...) Није било неко сажаљење према Вамој ситуаиији кад Вас је упропастио?).

[9] После ослобођења примио ме је у Араду исти командант Секуритате који ме је и отпремио. Чито сам јучер од ономадне да има већ шеснајс година од како је умро и чуди ме да после толиког времена није напредово у чину официра, само један степен, један град. Ја сам га мано мајор и умро је као потпуковник. Звао се Дамша Трајан, ако се, не верујем, не правим никакву, овај, разлику да кажем, био је Циганин. Мали, дебео, поткултуру колко може, али био је човек који је, како да Вам кажем, се уклопио добро у систем. Онај систем, или оном систему требали су такви људи. (ММ: Је био по мери сваког система, $\partial а, \partial а$.) После, кад смо дошли имали смо, овај, обавезу да у року од две недеље, петнес дана да се. (ММ: Није било неко сажаљење према Вашој ситуаиији кад Вас је упропастио?) Никад. Само ћу Вам стићи да Вам приповедам, мислим да једног датог момента ${ }^{46}$ имо је неки трзај савести. У року од две недеље требали смо да се ангажујемо да радимо. Ја у столарији, што сам познавао, а мој друг Гјоргов, овај, био је тапицер ${ }^{47}$. Нико није тео да нас прими. Кад смо однели документа, и овај каже: „Дођите сутра”, не знам шта, један чак у фабрици вагона секретар партије нам је казо јасно неће да сам себи прави проблеме. Будући да ће да истече рок ми нисмо нигди били, овај, са радом, отишли смо натраг у Секуритате код Дамше. Примио нас је врло кратко, каже: „О чему је реч?” Причали смо, неће нико да нас прими да радимо и. „Не,” каже, „сете само оде.” Узо телефон, у оно време био је Oficiu forțelor de muncă ${ }^{48}$ Говорио је, неки Попа је био који, код њега смо били, „О, не може.” Дао му је Дамша телефон, каже: „Сутра, зајтре,” каже „у осам да сте код њега.” „У реду.” Идем кући у Наћфали, Титус ми колега у Винги је седео и зајтре идемо. Каже: „Dați documentele încoace ${ }^{49 ،}$ каже. „Uite, nu pot să vă dau un loc de muncă la întreprinderi de stat ${ }^{50}$," каже „,numa în cooperație. La voi scrie clar aicea muncă de jos ${ }^{51}$." Добро је, били смо радосни да ћемо имати једну плату и то ћеду ствари почети да теку нормално. Тако је и било. После нам је дао документа, отишли смо и, овај, запослили се. Гјоргов је радио једно двадесет година, ја сам чак радио двадесет и шест на исто место где нас је послао Дамша. Оданде могу да кажем да сам чак изашао у пензији ${ }^{52}$, али за

\footnotetext{
${ }^{46}$ Калк према румунском la un moment dat, 'у једном тренутку'.

${ }^{47}$ Рум. tapițer, 'тапетар'.

${ }^{48}$ Рум. Oficiu forțelor de mипсӑ, 'Биро рада' (дословно: 'Биро радне снаге').

${ }^{49}$ Рум. Dați documentele încoace, 'Дајте овамо документа'.

${ }^{50}$ Рум. Uite, nu pot să vă dau un loc de muncă la întreprinderi de stat, 'Види, не могу да вам дам радно место у државним предузећима'.

${ }^{51}$ Рум. numa în cooperație. La voi scrie clar aicea muncă de jos, 'само у кооперацији. Код вас овде јасно пише најнижи посао.'

${ }^{52}$ Калк према румунском: a ieși la pensie, 'отићи у пензију, пензионисати се'.
} 
цело време важио сам као сумњив елемент и стално су ме држали под присмотром, ствар коју ми је $\mathrm{e}^{53}$ после Револуције признао секретар Партије. [Jivko Ilin 2, 2010]

[10] Ја сам радио у, како то ви кажете, у пољопривреду, машине, машинска бригада, је л како? - Станица. - Станица. А све због комунизма. И ондак сам стиго у фабрику стругове у Арад. И тамо сам се разболо, дакле, сам имо један камен на бубрежак, сам био опериран и је било мора да напустим фабрику и сам ишо у робној кут’и у „Зиридаву” 54 , ходили сте тамо, не? Та велика робна кут’а у Арад. Тамо сам радио четрнес године ко бравар. И тамо су се донели из Загреба степенице. Добро сам казо, не? И је дошо један из фабрике који и мето на место. Тај се зове, па не знам, мош т'емо стит'и и на то. Се Фридрих Јозеф, неки Хрват, а швапско име. Је знао добро српски и човек са̂м, реко, „Хај, спавај код нас.” Не? Мислим доста лепо смо. И тако сам се упозно ш њима. На месец дана је дошо јопет, e, ја сам то, те степенице руководио, сам и мазо, сам и тако дал'е. [Торња, 2013]

Осим запослења у граду - не обавезно у фабрици - дефинитивни прекид са селом, показало се, представљало је добијање или (у периоду транзиције) куповина стана у граду $[8,11,14,15]$.

[11] После смо се приместили у Арад, тамо смо направили стан, то није државни, то смо ми, ми правили, још са две породице. Сад тај стан је остао, син тамо, само т'ерка још нема. Има стан, само није њен још. Кад т'емо тешко, не знам како правити да се купи и њози. [...] (БС: А ви сте га [земљотрес 1977] $u$ овде осетили?) Не, смо били у Арад, и деца су учили лекције. И ја седим тако и гледам децу, једаред бацим очи ${ }^{55}$ горе, полилеј ${ }^{56}$ почо да се љуља. Па кажем на децу ${ }^{57}$ : „Који сте стигли?” „Па нисмо, тато, ни један.” „Па гле га како се камит’а.” „Па нисмо ниједан.” „Море, па да л се мож тај сам дрмати?” Није трајало десет минута дође Иванка кут’и уплашена: „Сте живи сви? Живите сви?” „Да.” „Па је био земљотрес, па је пуко дувар у фабрику.” Па шта знам ја шта још. - Да, било. Бегали сви доле, так како смо били свучени, босе, зими. И после нико није тео више да се пење горе, ни да се обучемо, ништа, сви кући, које куд. [Торња, 2013]

\footnotetext{
${ }^{53}$ Калк према румунском: lucru care mi a, 'што ми је'.

54 Зиридава је дачки град који помиње Птоломеј у својој „Географији”, налазио се у Поморишју у околини данашњег Арада. Назив Зиридава носе данас многе комерцијалне организације у Араду (тржни центри, угоститељски објекти), као и археолошки часопис који издаје Музеј у Араду. Робна кућа „Зиридава”, коју помиње саговорник, била је саграђена 1978. године (Magazinul universal „Ziridava”).

${ }^{55}$ Калк према румунском: a arunca ochii, 'бацити поглед; погледати'.

56 Лексема полелеј, осим у основном значењу 'велики свећњак који виси насред цркве', у једном примеру из Врдника у Срему потврђује и значење 'лампа' (РСГВ).

57 Дијалектолог Драгана Радовановић (2019: 399) само код једне саговорнице запажа 'тенденцију ка аналитизму' (њени примери су из Наћфале: казала на деду, казала на мене). Као и у овом примеру из Фелнака (кажем на децу) у питању је калк према румунском где се у говорном језику уз глаголе говорења често користи акузатив са предлогом (*spun la copii).
} 
Зарада од неформалне економије у периоду комунизма, било у граду [14], или у родном селу $[7,8]$, која је омогућавала додатне приходе али подразумевала и велика одрицања, ипак није била опште место [12]. Или, бар, није била тема о којој се говори непознатом истраживачу.

[12] (Ch: А у Арадy? Радили сте негде?) Сам радила прво у фабрику од конфекцији ${ }^{58}$ и после сам радила у продавницу, „Зиридаву”. Сам правила школу економик ${ }^{59}$ две године још, и сам. „Зиридаву” за кад су водили Срби у „Зиридаву" тамо сам била увек. (CЋ: A, кажите ми, нисте радили као шнајдерка? Да сте шили?) Не. Нисам радила партикуларно ${ }^{60}$, не. Кући сам почела врло мало ал сам се удала млада, од седамнес године и онда кад сам дошла овде нисам радила, нисам познала, ни не познам никог, онда кад сам ишла у Арад тамо сам радила у фабрику, ето шнајдер. [Торња, 2013]

[13] Волем, но, велико коло, мало коло, сељачицу ${ }^{61}$, јел Жикино коло, у-у, то сам играла, Жикино коло, боже мој! Да сам, све сам и крљала, све, све, сам здраво играла. И кад сам била у Араду, кад смо седили тамо у цркву, онак је био, на Петровдан била слава, а ови, има тамо, баш у цркву смо седили, тамо последњи онај стан тамо, но, и ондак, ови ту су били само Цигани, су седили, богати Цигани, онак кад је била слава, онак они дођеду па вичеду, тако су ме звали: „Hai sârboaico, nu te lasa!”’2 A ја сам играла ондак само тако. А они само вичеду: „Немој се манти.” [Наћфала, 2013]

[14] Неки попа био у Арад, Рајић Стева ${ }^{63}$ се звао, а ја сам био у Арад, тако некако онда оно време сам био појац већ у цркву, ја сам појац, појим, појим у цркву. Е дође попа тај из Арада код мене, ме чуо у Арад тамо де сам појо, ја сам био у цркву, каже: „Милане, знаш шта сам дошо? Ми треба један појац у Арад, нећеш ти да дођеш,” каже, „у Араду?” У-у, мало ми је било незгодно, живе ми отац и мати. А мој отац каже и слуша, ту смо седили, у соби, ту. Мој отац каже: „Ја сам слушо сад све и ја би казо тако. Ја би те светово,” на мене, отац, „имаш два сина, имате.” А они су били онако млади, дечурлија, деца. Каже: „Кад господин те иште, те траже д идеш у Арад, иди,” каже. „Не за тебе и за Олгицу, за супругу, за децу,” каже, „ите. Тамо ћеду ићи у школу, а нас двоје,” каже, „манте нас, смо стари већ, а како можемо тако ћемо се одмрсти ${ }^{64}$ нас двоје. А ви ите због деце.” И тако ме убеди, отиднем у Арад појац. Шеснес година. (СЋ: Живели сте у Араду?) Тамо смо живели и ја и супруга и

\footnotetext{
${ }^{58}$ Калк према румунском: fabrica de confecție.

${ }^{59}$ Рум. Liceu/Colegiu economic 'економска школа'.

${ }^{60}$ Према рум. particular, 'приватан'.

${ }^{61}$ Коло „сељанчица”.

${ }^{62}$ Рум. Hai sârboaico, nu te lasa! 'Хеј, Српкињо, не пуштај се!”

${ }^{63}$ Прота Стеван Рајић био је парох у Араду од августа 1979. све до пензионисања 2004. године (Бугарски, 2009: 28-30).

${ }^{64}$ Вероватно калк према румунском: a descurca, 'снаћи се'; РСГВ уз лексему одмрсити, бележи само значења 'расплести' и 'помирити завађене'.
} 
деца. А отац и мати су ми остали сами оде. Ми смо отшли тамо, сам имо стан, баш у, баш у цркви, ди је црква. Да, није био стан велики, како да кажем, једна соба, кујна, за нас је било доста. Кажем, тамо смо спровели шеснес година. Послен тога ми умрла мати, осто ми отац сам. [...] Па, како да Вам кажем, ни ми је било хрђаво, нисам радио да кажеш да сам се убиво од радње. Ето шта сам имо, ја сам чистио цркву и ван цркве, напоред, поред цркве, ту сам ја све држо у реду цркву унутра и, и појо. Нисам радио тешко, како да кажем. А друго нисам радио да кажеш да сам се убиво од радње, не. (CЋ: $E$ cy Baм деца иила у школу онда у Араду?) Да, да, да. Су били у школу. И тако, онда сам се вратио натраг и тако прошло. Прошле године, шеснес година. [...] (Ch: Које то било време, које године сте били, отприлике?) То је било шездесет и осме, шездес девете до, до осамдесете скоро. Да, седамдес девете сам дошо, сам се повуко натраг. [...] А ми је било жао онда кад сам се вратио натраг, сам био научен већ, мож да замисте, шеснес година, није било шеснес дани, ипак. Деца су били, тамо су ишли у школу, тако да. Супруга, и она била ангажована, тамо на ћошак од цркве је била нека зграда, то је била зграда црквена, и сад је црквена, та. Ал једно време извесно, нике године, за време комунизма, је био комунизам још, је била одузета та зграда, је био неки петрол. Петролиум, тамо су били неки инџилири ${ }^{65}$ и супруга ми је била ангажована код њи тамо. Је радила на неки овај, како се каже, треба да знате Ви шта је то, серокс, ${ }^{66}$ је вукла на серокс, правила тамо неке планове, неке шта знам. Тамо је била ангажована код њи. Није била кући, тамо. Тако, прошли смо, се вратили натраг и данашњи дан смо оде. Отац ми је умро, кажем, мати ми је умрла пре, отац живио сам николко година и тако су прошле године. Моје године су прошле, седамдест и четир. [Наћфала, 2013]

[15] (Ch: А, кажите ми, Нова година како се слави? Та, као српска.) Српска Нова година увек, увек. Мислим, у Араду се скупимо и славимо, да, славимо Срби у Араду. Тамо смо више Румуни него Срби. И Румуни дођеду на нашу Нову годину, воледу, воледу, мислим, воледу. На, тамо се и састанемо на српску Нову годину и на, кад славимо Светог Саву. Ондак се састанемо, Срби. Сви Срби из околина Арада. Не само у Араду. (СЋ: То баш y, у граду Араду?) У граду Араду. Да, у граду Араду. (СЋ: То је у оној иркви, да?) Да. У српској цркви и после, да, идемо негде где се слави, у позориште или, мислим, на Светог Саву. [...] Ја живим уопште у Арад, тамо радим, још радим и тамо станујем, али дођем сваког петка кући у Мунару. [...] (CЋ: А кад сте прешли да живите у Араду?) После револуције, деведест прве године сам отишла у Арад и од онда сам тамо остала. Сам откупила стан тамо и тамо сам остала, тамо сам радила даље и. Да, после револуције, деведест и прве године. До онда сам била у колектив. [Мунара, 2014]

\footnotetext{
${ }^{65}$ Иниилир, 'инжењер'. РСГВ потврђује ову лексему у истој форми у многим банатским насељима: Јасенову, Новом Милошеву, Томашевцу, Иђошу, Итебеју, Орловату, али и у градовима - Суботици и Новом Саду. У Румунији је лексема забележена у Иванди и Ченеју.

${ }^{66}$ Рум. хегоx, 'ксерокс, апарат за копирање'.
} 


\section{Тамо сам рођен, тамо}

Последња три наратива одабрана су да илуструју постојећу носталгију за родним селом, разлоге за потпуни или делимични повратак, истовремено се преклапајући са сећањем на дане младости и живота у великим породичним заједницама.

[16] (БС: Овде је лепо, здрав живот.) Па, како је, шта да радимо. Ми смо задовољни. И не знам ако знате ту песму „Ова кут’а не се прода, ни околина, ова кут'а је моја дедовина.”'67 (БС: Не знам ту песму.) Не знате ту песму? О, ови Срби из Маџарске певају често ово, ху, лепа песма је. Ја толико сам желио да се приместимо у Торњи. Овде је било опако, ја вам кажем, не ме верујете, пошто сам био тамо у робној кут'и четрнес године, ја сам водио бригу за те степенице. [...] Каже Иванка: „Не јеш?” „Не треба ми.” „Па кад си јео?” „Не знам, не, не треба." Нот'ом не могу да спавам. Сам осетио ја нешто, беде имам, штогод'. Хајд да идем код доктора. Идем код доктора, оти ме гледају, тражу: „Ai, ceva bai aveți68, штогод имате, ал не знамо шта имате.” Но, сам стиго код комисије да ме метеду у мировину. То је било деведесет и друге. Су ме метли у мировину и су казали: „Не, кажемо право, не знамо шта имате.” Сам стиго у Торњи $[\ldots]$ и да вам кажем, сам стиго у Торњи и мама још је живила, сам почо да јем, сам почо да спавам и ондак сам чуо јел у Маџарску у робној кут'и „Корвин” ${ }^{69}$ је умро тај кој је водио бригу за степенице, би био и ја ирадиран ${ }^{70}$, не бисте били познали. [Торња, 2013]

[17] (БС: А радите земљу сад?) Не, не радим више земљу, имамо земље ал сву сам је дао у аsociație ${ }^{71}$, што сам [?] за земљу, не држимо, нисам оставио ништа, само једну реморку ${ }^{72}$, оно све друго све сам продо да не радим више. А радим, помогнем сину, ја сам инџилир, син ми инџилир, и ми правимо пројекте за куће, воду, све, све шта треба. Да, и посо он узме доста много да ради и онда „Хај, тато, помози ми.” Онак тата треба да му помогне, шта да радим, онак правимо овдена, идемо у Арад и опет дођем, то треба да радим. [Наћфала, 2013]

[18] Ја и радим тако по кући и помалко, као по башту, то. (БС: А има нещто живине, имате?) Не држим зашто, гледајте, ја једаред дођем у Арад, ни

\footnotetext{
${ }^{67}$ У питању је рефрен народне песме „Није кућа на продају, ни кућа ни околина, та се кућа не продаје, то је моја дедовина.” Позната је у извођењу Снежане Бабић - Снеки, али је певају и други певачи народне музике.

${ }^{68}$ Рум. Ai, ceva bai aveți, 'неку болест имате'.

${ }^{69}$ Позната велика робна кућа у Будимпешти, Corvin Áruház.

${ }^{70}$ Немачки radieren, 'избрисати'.

${ }^{71}$ Рум. asociație, 'удружење'. Саговорник користи овај савремени румунски термин вероватно зато што су практично синонимни термини задруга или колектив везани за специфичне и негативно маркиране реалије из периода комунизма.
}

${ }^{72}$ Рум. remorcă,'приколица.' 
свиње више не. Зашто, данаске је недеља, а сутра је светац, ел имам сарану, а немаш више твоје Србе да кажеш: „Еј, иди, нарани ми пилиће. Иди, дај свиње." Немаш више кога, ја морам да закључам све и да. Не, ништа не држим, не. (БС: Само башту.) Само башту. Кромпира, пардајса, паприке, воћа свакојаке феле сам мето, е саде, кад су биле трешње, те трешње сам доно код Бранкине, то не Бранка, њена свекрва, пет ведре, редом тако трешње. Онда капшуне $^{73}$ сам платио једну жену, ја не могу да с леђима да стојим, два сата ми обрала четир ведре. Сам и доно капшуне, тако. Сад је трава у капшуне, сад треба да и чупам, да и очистим, да и окопам, да. Имам грожђа, све је ово олтовано $^{74}$, не много, за нас тако метуто. Тамо тако живим, тамо сам рођен, тамо, и кад помислим била пуна кућа и сад сам осто сам. Тако, не знам како, знате, није више као оно како било пре, било деда, мајка, мама, тата, ја, сестра, шест у кућу смо били. Од ти шест ја сам сам остао. Ако споменем сад у село, па све српске куће су биле, све српске, сада је готово, како да вам кажем, сокаци, све Срби, Срби. [Арад, 2015]

\section{Завршне напомене: јавни простори града и села у Поморишју}

Причања о животу интерполирана у полуструктурирани интервју чији је основни циљ била језичка документација и само неколико тема везаних за традицијску културу (Божић, свадба, црквена слава, усмена историја социјализма - рад у задрузи - колективу, страдање у Барагану...) одликује фрагментарност: у питању су (од стране аутора прилога обликоване) фрагментарне наративне секвенце које међусобно повезује само 'простор' родно село и/или (град) варош Арад. Употреба термина град уместо уобичајеног локалног: варош, чини се, била је сугерисана од стране истраживача (То баш y, у граду Араду?) У граду Араду. Да, у граду Араду. [15], или је условљена саговорниковом потребом да свој говор прилагоди истраживачу: ниси имо булетин за варош, за град ниси мого да [8]; правим булетин за град (...) сам ја имо булетин за град [8]. Чешће је, посебно у спонатаној нарацији: И пошли у варош, отишли [1]; стари људи млоги су отишли у варош [2]; кад имаш булетин за варош да имаш абонамент [8], булетин види да имаш за варои [8].

Истраживач, са своје стране, покушава да прихвати аутентични локални термин: ако немаш булетин за варош не можеш да купиш блок. (БС: Иако радите, иако имате посо у варошу?) [8].

За крај прилога преостало је једно могуће језичко и антрополошко одређење тачака које у усменим историјама Поморишја маркирају простор града / урбаност у односу на руралне просторе, али треба имати у виду да

\footnotetext{
${ }^{73}$ Рум. capșună, 'јагода'.

${ }^{74}$ Олтован, - $a$, -о, 'калемљен'. РСГВ бележи ову лексему углавном у Банату, са потврдама и из Румуније (Ченеј и Иванда).
} 
су наративима временски хоризонти измешани и често се преклапају периоди комунизма и транзиције (за слична разматрања уп. Богдановић, 2020; Rogaly, Qureshi, 2017).

Село као простор у поморишким наративима дефинишу: куће, сокаци, башта [18], колектив [15], земља, asociație [17], црква [2, 14], Велики сокак [3], шопра [8]. Саговорници могу да наброје све куће у селу и сви становници се међусобно познају: овде Срба има око двадесет, двадесет и три лица (...) једно дванајс куће [1], како да вам избројим тако, само ту на Велики сокак треба да имамо, један, два, три, четир, пет, шест, седам, осам [3].

Са друге стране, варош Арад у просторном смислу одређују: српска црква, позориште, стан [15], робна кућа [16], школа [6, 12, 14], стан [11, 14], црква [13, 14], зграда [14], фабрика [4, 5, 8, 10, 11, 12], продавница [12], робна кућа [10], гарсоњера [8], стадион [6], кућа, сокак [7], блок [8], предузеће [8]. Приватни простор у граду ограничен је станом.

Транскрипти су у овом прилогу организовани у форми текста који има документарну вредност на више нивоа (у том смислу и лингвистичку јер представља дословни транскрипт разговора), тако да могу да се читају одвојено од ауторских коментара. Ипак, одлука о избору одломака из некада веома обимних транскрипата, као и њихов распоред, били су ауторски: постигнути резултат у форми полилога омогућио је да се чују гласови 15 различитих саговорника (са различитим наративним могућностима), уз три истраживача који су те разговоре усмеравали у зависности од својих личних научних интересовања. Овај прилог је тим приређивачким поступком задобио својеврсну 'књижевну' структуру коју карактеришу промена перспективе и комплементарни или дисјунктивни односи одабраних наратива. Лингвистичка апаратура (уз минималне фолклористичке коментаре), 'склоњена' у напомене испод основног текста, ојачала је научну димензију прилога.

\section{Литература:}

Богдановић, 2020: Бојана Богдановић, Град као метатекст: студије из српске урбане антропологије, Гласник Етнографског института САНУ LXVIII/1, $7-12$.

Бошњаковић, Радан, 2010: Жарко Бошњаковић, Михај Радан, Досадашња истраживања утицаја румунског језика на лексику српских говора у румунском делу Баната, Јужнословенски филолог LXVI, 135-161.

Бошњаковић, Урошевић, 2013: Жарко Бошњаковић, Данка Урошевић, О релативизатору шта у српским говорима румунског Баната, Српско језичко наслеђе на мултикултурном простору Баната (М. Радан, прир.), Темишвар: Савез Срба у Румунији, 7-26. 
Бугарски, 2004: Стеван Бугарски, Срби у Темишвару, Теме 2, Ниш, 765-778.

Бугарски, 2009: Стеван Бугарски, Свештеници Текелијине цркве у XX веку, Арад кроз време 10, Темишвар, 23-30.

Бугарски, Степанов, 1991: Стеван Бугарски, Љубомир Степанов, Кад Мориш потече кроз перо, Букурешт: Критерион.

Бугарски, Степанов, 2008: Стеван Бугарски, Љубомир Степанов, Срби у Темиивару. Град, Темишвар: Савез Срба у Румунији.

Бугарски, Степанов, 2011: Стеван Бугарски, Љубомир Степанов, Срби у Темиивару. Мехала, Темишвар: Савез Срба у Румунији.

Драгин, 2020: Гордана Драгин, Међу Србима у Румунији, На темељима народних говора, Зборник радова посвећен проф. др Јордани Марковић (Т. Трајковић, Н. Јовић, ур.), Ниш: Филозофски факултет, 181-190.

Думнић, 2017: Марија Думнић, Носталгија у интерпретацији тамбурашких оркестара у Темишвару 2016. године: староградска музика и тамбураштво. Исходишта 3, Темишвар - Ниш, 119-127.

Касаш, 2020: Јована Касаш, Свакодневни живот Срба у Темишвару пре и након завршетка Првог светског рата, Исходишта 6, Темишвар - Ниш, 163-172.

Марков Јоргован, 2001: Јаворка Марков Јоргован, Линија поморишке војне крајине, Арад кроз време, Темишвар: Савез Срба у Румунији, 83-85.

Марков Јоргован, 2015: Јаворка Марков Јоргован, „Лебац је божје лице” (обредни хлеб и жито код поморишких Срба), Исходишта 1, Темишвар - Ниш, 201-210.

Милин, Милин, Михајлов, 2011: Андреј Милин, Миодраг Милин, Цветко Михајлов, Срби у Румунији за време комунизма, Темишвар: Савез Срба у Румунији.

Неделку, Чолевић 2016: Октавија Неделку, Лидија Чолевић, Срби у Букурешту. Општи приказ, Исходишта 2, Темишвар - Ниш, 159-170.

Неделку, Чолевић, 2017: Октавија Неделку, Лидија Чолевић, Срби у Букурешту. Идентитет, Исходишта 3, Темишвар - Ниш, 277-284.

Павловић, 2012: Мирјана Павловић, Срби у Темишвару, Београд: Етнографски институт САНУ.

Петровић, 2015: Соња Петровић, И град и варош: сећања на свакодневни живот у предратном Београду, Гласник Етнографског института САНУ LXIII/1, 85-99.

Петровић, 2018: Соња Петровић, Свакодневни живот на улицама Београда: обликовање личних сећања у усменој историји и аутобиографској прози, Научни састанак слависта у Вукове дане 47, Београд: МСЦ, 95-106.

Радовановић, 2019: Драгана Радовановић, О дијалекатским особеностима Наћфале у румунском Банату - извештај са терена, Исходишта 5, Темишвар - Ниш, 389-402.

РСГВ: Речник српских говора Војводине 1-10, Нови Сад: Матица српска, 20002010. 
Сикимић, 2015: Биљана Сикимић, Срби у Поморишју: сећања на војну границу, Усмена традиција Банатске војне границе (М. Матицки, ур.), Нови Сад: Матица српска, 133-160.

Сикимић, 2016: Биљана Сикимић, Обредна јела у Војводини и Поморишју приликом клања свиња. Савремена теренска истраживањаSlavische Geisteskultur: Ethnolinguistische und philologische Forschungen. Teil 1, (Alekseev, Anatolij A. etc. Hrsg.), Philologica slavica vindobonensia 2: Frankfurt am Main [u.a.], 157-180.

Сикимић, 2019: Биљана Сикимић, Станчево: наративи о раду и сиромаштву, Исходишта 5, Темишвар - Ниш, 403-424.

Степанов, Бугарски, 2004: Љубомир Степанов, Стеван Бугарски, Демографска слика Поморишја после сеобе Срба у Русију, Арад кроз векове 5, 7-21.

Степанов, Степанов, 2014: Љубомир Степанов, Весна Степанов, Статистички подаии о Србима у Румунији, Темишвар: Савез Срба у Румунији.

Трубарац Матић, 2019: Ђурђина Трубарац Матић, Славски обичаји у румунском Поморишју (Чанад, Фелнак) и Банатској Црној Гори (Краљевац): резултати теренског рада обављеног у јулу 2018. године, Исходишта 5, Темишвар Ниш, 465-474.

Ћирковић, 2004: Светлана Ћирковић, Мек љеб ко сунђур да једеш, Лицеум 8, Избегличко Косово (Б. Сикимић, ур.), Крагујевац: Центар за научна истраживања САНУ, 85-108.

Ћирковић, 2015: Светлана Ћирковић, Истраживања српских заједница у жупанији Арад у Румунији: антрополошколингвистичка анализа наратива о прављењу [чеснице], Исходишта 1, Темишвар - Ниш, 455-472.

Ћирковић, 2017: Светлана Ћирковић, Настава на српском језику у Поморишју данас, Исходишта 3, Темишвар - Ниш, 519-536.

Церовић, 2007: Љубивоје Церовић, Срби у Араду, Нови Сад: Музеј града Новог Сада.

Шандић, 2011: Љубомир Шандић, Монографија српске заједнице из Арад Гаја. O намем благу, Арад Гај: Издање аутора.

Шандић, 2012: Љубомир Шандић, Монографија српске заједнище из Арад Гаја. To je мој Гаj, Arad: Editura Promun.

Ćirković, 2015: Svetlana Ćirković, Tradiţia vie a sârbilor din judeţul Arad: cesniţa (česnica). Elena Rodica Colta (coord.). Populaţii şi Patrimoniul Imaterial Euroregional. De la stratul cultural profund la tradiţii vii. Bucureşti: Centrul Cultural Judeţean Arad. Editura Etnologică, 148-176.

Ćirković, 2016: Svetlana Ćirković, Food as intangible cultural heritage - the česnica among Serbs in Romania. Porta Balkanica VIII, volume 1, 29-42.

Colta, 2010: Elena Rodica Colta, Interetnicitate și construcții identitare în zona de frontieră româno-maghiară, Arad: Editura Universității „Aurel Vlaicu”.

Markov Iorgovan, 2018: Iavorca Markov Iorgovan, Cusăturile populare, parte a culturii naționale a sârbilor mureșeni, Patrimoniul și patrimonialazare (coord. E.R. Colta), București: Editura etnologică, 115-125. 
Marković, 2012: Jelena Marković, Pričanja o djetinjstvu: život priča u svakodnevnoj komunikaciji. Zagreb: Institut za etnologiju i folkloristiku.

Milin, 2003: Andrei Milin, Familia tradițională sârba în Banatul românesc, Timișoara: Editura Presa Universitară Română.

Niţu, 2017: Arad, economie şi societate 1945-1989, I-III, (Adrian Henorel Niţu, coord.), Cluj Napoca: Presa Universitară Clujeană.

Sikimić, 2015: Biljana Sikimić, Obiceiurile legate de tăierea porcilor la sârbi de pe Valea Mureşului (Pomorišje). Cercetări de teren contemporane, Populaţii şi patrimoniul imaterial euroregional. De la stratul cultural profund la tradiţii vii (E. R. Colta, coord.), Bucureşti: Editura etnologică, 119-147.

Rogaly, Qureshi, 2017: Ben Rogaly, Kaveri Qureshi, 'That's where my perception of it all was shatterd': Oral histories and moral geographies of food sector workers in an English city region, Geoforum 78, 189-198.

Biljana Lj. Sikimić

\section{SERBS IN THE RIVER MUREȘ/MAROS/MORIŠ REGION: BETWEEN VILLAGE AND TOWN}

\section{Summary}

Based on the fieldwork research of Serbs in Arad county (Romania) done in 20132015 , the paper analyzes narratives about personal relocation to the city of Arad and elements of biographical stories given in the form of digressions in narratives covering the themes of traditional Serbian culture. Collected material comes from the settlements of Nadjfala/Satu Mare, Felnak/Felnac, Monoštor/Mănăştur Munara/Munar, Tornja/Turnu, town of Arad, as well as from published memories of the victims of communism. The time period covered in the narratives starts from the period of communism, through the Revolution of 1989, all the way to the modern, parallel world and double life in the villages and Arad at the same time. The narratives are divided into five thematic units that cover the current situation in the settlement, memories of the Felnac tamburitza orchestra, trips to Arad from a children's perspective, fragments about everyday life in Arad and today's situation of emotional division between the village and the city. The attached transcripts are verbatim and reflect the different degrees of preservation of the Serbian language (Šumadija-Vojvodina dialect) and the corresponding influence of the Romanian language in each individual participant.

Key words: depopulation, labor migration, Serbs in Romania, oral history, biographical stories, Arad. 